\title{
Formulasi Pembuatan Sediaan Eyeshadow dari Ekstrak Bunga Kecombrang (Etlingera elatior Jack)
}

\author{
Bunga Rimta Barus, S. Farm, M.Si.,Apt.) $)^{1)}$ Vera Estefania Kaban, S.Farm., \\ Apt. $)^{2)}$ \\ Institut Kesehatan Deli Husada Delitua \\ Jalan Besar Delitua no. 77, Kab. Deli Serdang, Sumatera Utara \\ E-mail : bungarimtabarus@gmail.com \\ DOI: https://doi.org/10.35451/jfm.v1i2.145
}

\begin{abstract}
One type of cosmetic or decorative cosmetic preparation is eyeshadow which contains a color pigment applied to the eyelid. The purpose of this study was to find out that kecombrang flower extract can be used as eyelid coloring. From the study to make eyeshadow preparations using dyes extracted from kecombrang flowers, to determine the stability of the eyeshadow by using kecombrang flower extract in storage at room temperature, and to find out whether eyeshadow preparations using extracts from kecombrang flowers cause irritation when used. Eyeshadow preparations from kecombrang flower extract (Etlingera elatior Jack) were made in various concentrations of $15 \%, 17.5 \%$, $20 \%, 22.5 \%, 25 \%$ and blank preparations (without using kecombrang flower extract). Physical quality inspection of the preparation includes: color dispersion test (homogeneity), cracking test, and stock stability test. And for other tests carried out polishing tests (homogeneity) and irritation tests. Eyeshadow from kecombrang flower extract also does not cause irritation and is stable in room temperature storage for 30 days. Preparation of kecombrang flower extract with several good concentrations was used as eyeshadow preparations, stable eyeshadow preparations in storage at room temperature within 30 days, and the formulation of eyeshadow preparations using kecombrang flower extract as eyelid coloring did not cause irritation.
\end{abstract}

KataKunci: bunga kecombrang, pembuatan eyeshadow.

\section{Pendahuluan}

Salah satu jenis sediaan kosmetik rias atau dekoratif adalah perona kelopak mata (eyeshadow) yang berisi pigmen warna yang diaplikasikan pada kelopak mata. Komposisi eyeshadow terdiri dari pretoalum, lanolin, ceresin, kalsium karbonat, metil selulosa, talkum, pengawet, dan serbuk pemberi efek berkilau. Variasi warna yang terdapat pada eyeshadow dapat digunakan untuk memberi bayangan yang menarik pada bagian mata. Perona kelopak mata umumnya berwarna biru, merah muda, merah tua, perak, hijau dan coklat (Amalulia, 2016).

\section{METODE}

\section{Sampel}

Pengumpulan sampel dilakukan secara purposif yaitu tanpa membandingkan daerah lain. Sampel yang digunakan adalah bunga kecombrang yang diambil 
dari Pasar Simpang Limun, Kelurahan Sitirejo II, Kecamatan Medan Amplas.

\section{Bahan}

Bahan tumbuhan yang digunakan dalam penelitian ini adalah kelopak bunga kecombrang. Bahan kimia yang digunakan antara lain: asam sitrat, etanol 96\%. Bahan formulasi eyeshadow : gliserin monostearat, gom, lanolin wax, magnesium karbonat, parfum aroma mawar, pewarna (ekstrak kental bunga kecombrang), talk, titanium dioxide, zink stearat.

\section{Alat}

Alat yang digunakan yaitu batang pengaduk, beaker glass $1.000 \mathrm{~mL}$, botol kaca coklat, cawan penguap, cawan petri, gelas ukur $1.000 \mathrm{~mL}$, gelas ukur $10 \mathrm{~mL}$, kertas saring, kertas perkamen, lumpang, penangas air (waterbath), pipet tetes, rotary evaporator, sendok tanduk, sudip, stamper, tempat eyeshadow, timbangan elektrik, toples kaca.

\section{Pengolahan Sampel}

Bunga kecombrang segar dicuci bersih, lalu ditiriskan. Potong bunga kecombrang menjadi bagian yang lebih kecil lalu timbang sebanyak $2 \mathrm{~kg}$. Bunga kecombrang sebanyak $2 \mathrm{~kg}$ yang telah dihaluskan dimaserasi dengan 1,5 L etanol $96 \%$ yang telah dicampur dengan $30 \mathrm{~g}$ asam sitrat, lalu ditutup dan dibiarkan selama 5 hari terlindung dari cahaya matahari sambil sering diaduk. Kemudian ampas dimaserasi kembali dengan etanol $96 \%$ yang telah dicampur dengan $10 \mathrm{~g}$ asam sitrat sebanyak 0,5 L selama 2 hari, lalu saring dengan kain kasa. Hasil yang diperoleh dicampur dengan filtrat pertama lalu diuapkan dengan bantuan alat rotary evaporator pada temperatur $\pm 500 \mathrm{C}$, kemudian diwaterbath (Nurhayati, 2016).

\section{Formulasi Pembuatan Eyeshadow}

Tabel Formulasi pembuatan eyeshadow

\begin{tabular}{|l|l|l|}
\hline Bahan & Jumlah & Fungsi \\
\hline $\begin{array}{l}\text { Magnesium } \\
\text { karbonat }\end{array}$ & $1 \mathrm{~g}$ & $\begin{array}{l}\text { Efek covering } \\
\text { (matte) }\end{array}$ \\
\hline Zink stearat & $1 \mathrm{~g}$ & Perekat bahan \\
\hline $\begin{array}{l}\text { Titanium } \\
\text { dioxide }\end{array}$ & $2 \mathrm{~g}$ & Pengawet \\
\hline Gom & $0,4 \mathrm{~g}$ & Pengikat \\
\hline $\begin{array}{l}\text { Gliserin } \\
\text { monostearat }\end{array}$ & $0,1 \mathrm{~g}$ & Melicinkan \\
\hline Lanolin wax & $1,5 \mathrm{~g}$ & Melicinkan \\
\hline Talk & $2 \mathrm{~g}$ & Bahan pengisi \\
\hline Parfum & $2 \mathrm{ml}$ & Pewang \\
\hline
\end{tabular}

\section{Cara Pembuatan}

Siapkan semua alat dan bahan, lalu timbang semua bahan sesuai prosedur. Masukkan magnesium karbonat, zink stearat, titanium dioxide, talk, gliserin monostearat kedalam lumpang 1 , gerus hingga homogen. Lalu lebur lanolin wax pada waterbath. Siapkan lumpang panas, masukkan leburan lanolin kedalam lumpang panas kemudian ditambah campuran lumpang 1 (magnesium karbonat, zink stearat, titanium dioxide, gliseril monostearat) dan gerus hingga homogeny, masing-masing tambahkan pewarna dari ekstrak bunga kecombrang dengan konsentrasi 15\%, 17,5\%, 20\%, $22,5 \%$, 25\%. Masing-masing sediaan masukkan kedalam wadah.

\section{HASIL DAN PEMBAHASAN}

\section{Pemeriksaan Fisik Eyeshadow}

Eyeshadow dengan konsentrasi pewarna ekstrak bunga kecombrang 15\% $17,5 \%$ dan $20 \%$ berwarna merah jambu, sedangkan konsentrasi $22,5 \%$ dan $25 \%$ berwarna merah jambu tua. Aroma eyeshadow adalah aroma khas parfum dari oleum rosae. Rasa ekstrak dari bunga kecombrang asam.

\section{Pemeriksaan Mutu Fisik Eyeshadow}




\section{a. Uji Dispersi Warna (homogenitas)}

Hasil pemeriksaan dispersi warna eyeshadow menunjukan bahwa sediaan yang dibuat terdispersi merata dan tidak ada warna yang berbeda atau tidak merata pada saat ditaburkan pada kertas putih.

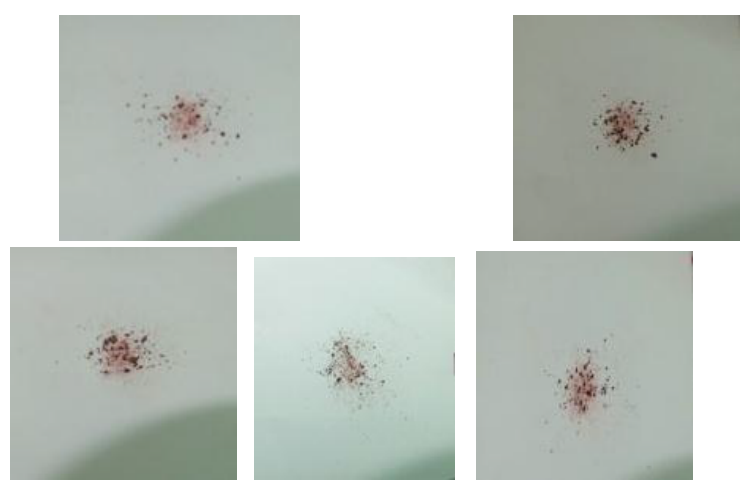

Keterangan :

Sediaan 1 : Formula tanpa ekstrak bunga kecombrang (blanko)

Sediaan 2 : Formula dengan konsetrasi ekstrak bunga kecombrang $15 \%$.

Sediaan 3 : Formula dengan konsetrasi ekstrak bunga kecombrang $17,5 \%$.

Sediaan 4 : Formula dengan konsetrasi ekstrak bunga kecombrang $20 \%$.

Sediaan 5 : Formula dengan konsetrasi ekstrak bunga kecombrang $22,5 \%$.

\section{b. Uji Keretakan}

Hasil pemeriksaan yang didapat terhadap sediaan eyeshadow dengan uji keretakan menunjukan bahwa semua sediaan yang dibuat tidak pecah.

\section{c. Uji Stabilitas}

Hasil uji stabilitas sediaan eyeshadow menunjukkan bahwa seluruh sediaan yang dibuat tetap stabil selama penyimpanan pada suhu kamar selama 30 hari pengamatan. Parameter yang diamati dalam uji kestabilan fisik ini meliputi perubahan bentuk, warna dan bau sediaan. Dari hasil pengamatan bentuk, didapatkan hasil bahwa seluruh sediaan eyeshadow yang dibuat tidak terjadi perubahan bentuk dari bentuk awal pencetakan sampai selama 30 hari pada penyimpanan suhu kamar.

\section{Uji Iritasi dan Uji Poles a. Uji Iritasi}

Berdasarkan hasil uji iritasi yang dilakukan pada 10 orang panelis yang dilakukan dengan cara mempoleskan sediaan eyeshadow pada pada luas tertentu $(2,5 \mathrm{x}$ $2,5 \mathrm{~cm}$ ) pada lengan bawah bagian dalam dan dibiarkan terbuka selama lebih kurang 24 jam menunjukkan bahwa semua panelis memberikan hasil negatif terhadap reaksi iritasi yang diamati yaitu eritema, papula, vesikula atau edema.

\section{b. Uji Poles}

Sediaan eyeshadow menghasilkan polesan yang baik maka sediaan memberikan warna yang intensif merata dan homogen saat dipoleskan pada kulit punggung tangan. Berdasarkan uji poles diperoleh hasil bahwa sediaan yang menghasilkan pemolesan yang baik sediaan pada konsentrasi $15 \%, 17,5 \%$ dan $20 \%, 22,5 \%$, dan $25 \%$. Hal ini ditandai dengan satu kali pemolesan sediaan telah memberikan warna yang jelas saat dipoleskan pada kulit punggung tangan.

\section{Kesimpulan}

Sediaan ekstrak bunga kecombrang dengan beberapa konsentrasi baik digunakan sebagai sediaan eyeshadow. Sediaan eyeshadow stabil dalam penyimpanan pada suhu kamar dalam waktu 30 hari. Formulasi seediaan eyeshadow menggunakan ekstrak bunga kecombrang sebagai pewarna kelopak mata tidak .

\section{DAFTAR PUSTAKA}

Adliani Nur, Nazliniwaty, Djendakita. (2012). Foemulasi Lipstik Menggunakan Zat Warna Dari Ekstrak Bunga Kecombrang (Etlingera elatior (Jack) R.M.Sm). Journal of 
Amalullia Diana. (2016). Analisis Kadar

Timbal ( $\mathrm{Pb}$ ) Pada Eyeshadow

Dengan Variasi Zat Pengoksidasi

Dan Metode Dekstruksi Basah

Menggunakan Spektroskopis

Serapan Atom (SSA).

Skripsi.Malang: Unnivesitas

Negeri Maulana Malik Ibrahim.

Ditjen POM RI. (1979). Farmakope

Indonesia. Edisi III. Jakarta.

Departemen Kesehatan

Republik Indonesia. Halaman 407.

Ditjen POM RI. (1995). Farmakope Indonesia. Edisi IV. Jakarta. Departemen Kesehatan Republik Indonesia. Halaman 1157.

Fatimah S, dkk. (2015). Penetapan Kadar Sakarin Minuman Ringan Gelas Plastic Yang Dijual di Pasar Beringharjo Yogyakarta. Jurnal. Sekolah Tinggi Ilmu Kesehatan Guna Bangsa: Yogyakarta.

Hamdani Syarif, dkk. (2012). Panduan Praktikum Kimia Analisis. Modul Praktikum Kimia Analisis. Sekolah 10 Tinggi Farmasi Indonesia. Bandung. Halaman 21.

Nurhayati Ifa. (2016). Pembuatan Blush On Dari Buah Naga. Skripsi. Semarang: Pendidikan Kesejahteraan Keluarga Fakultas Teknik Negeri Universitas Semarang.

Wulandary Dewi Fransiska, Augustina Dwi, Yulia 2017. Formulasi Pembuatan Eyeshadow Compac Powder Menggunakan Ekstrak Buah Bit. Skripsi. Surabaya: Fakultas Farmasi Universitas Katolik Widya Mandala (UWM) Surabaya 